\title{
The Role of Accounting for Intellectual Capital in Achieving Human Resources Value in Universities Applied to a Sample of Faculty Members at the Dongola University in the Sudan \& Abu Dhabi University in the United Arab Emirates
}

\author{
Ayman Abdalla Mohamed Abu Baker ${ }^{1}$, \& Modthir Hassan Salim Ezieldin ${ }^{2}$ \\ ${ }^{1}$ Academic Coordinator for the Financial Management Division, Military Programe, AbuDhabi Unevrsity, UAE \\ ${ }^{2}$ Faculty of Economics and Administrative Sciences, University of Dongola, Sudan \\ Correspondence: Ayman Abdalla Mohamed Abu Baker, Academic Coordinator for the Financial Management \\ Division, Military Programe, AbuDhabi Unevrsity, UAE.
}

Received: March 29, 2021

doi:10.5539/ibr.v14n12p174
Accepted: November 28, 2021

Online Published: November 29, 2021

URL: https://doi.org/10.5539/ibr.v14n12p174

\begin{abstract}
This study aimed to identify the accounting for intellectual capital and its role in the achievement of human resources value in universities, a case study of a selected sample of faculty members of the Faculty of Economics and Administration Sciences at Dongola University and the academic programs at Abu Dhabi University. The study problem is well represented in how accounting for intellectual capital functions in its major three components, (human capital, structural capital, relational capital) and how that achieves the value of human resources in the universities.

The study data has been analyzed using the Statistical Package for the Social Sciences program (SPSS). The study reached a number of results as follows: The results of the analysis of the Simple linear regression have also shown a strong correlation and statistically significant effect of overall independent study variables combined, (accounting for human capital, accounting for structural capital, accounting for relational capital) on the value of human resources in the tow universities.

The study concluded with a set of recommendations, including the following: The study recommended the management of the two universities to increase the attention to the accounting for intellectual capital together with its three components (accounting for human capital, accounting for structural capital, accounting for relational capital ) by mobilizing the potential energies within the university, in a manner that enhances the value of human resources.
\end{abstract}

Keywords: intellectual capital, accounting for intellectual capital, human resources value

\section{Introduction}

Intellectual capital has become the focus of the attention of business firms for its basic role in the existence and continuity and determination of the competitive position of these firms in the business environment. In view of the particular nature of the components of intellectual capital and its significance in the realization of the value of human resources in the firm. The literature of accounting thought has attempted to analyze the components of intellectual capital, with a view to measuring its value and the extent to which it affects the value of human resources in the firm. As a matter of fact, this position has rendered the subject of accounting for intellectual capital a field of great significance for the most par of accounting professional organizations. For instance, the International Accounting Standards Board (IASB) has issued the international accounting standards No (38) relating to the accounting for intangible assets. The Chartered Institute of Management Accountants (CIMA), on the other hand, has published many articles about the measurement and management and reporting on intellectual capital. This is in order to deal with the lack of traditional accounting systems to provide appropriate basis of accounting for intellectual capital. Despite the fact that, numerous study studies have dealt with the subject of accounting for intellectual capital, yet this subject represents a prolific area for accounting study in order to find out an integrated framework of accounting for intellectual capital. In light of said fact, this study paper aimed to identify the role of accounting for intellectual capital to achieve the value of human resources in 
the universities, particularly, the universities of Dongola and Abu Dhabi, by monitoring the viewpoints of the faculty members of the selected faculties as a sample on this subject.

Many previous studies have dealt with this subject from different angles, which will be enumerated pursuant to its precedence in time, in order to know the present development in this area. For instance, the study of Eric, (Eric Flamholtz, 1971), which entitled "Should your Organization Attempt to Value its Human Resources" has put forward a number of questions to measure the effectiveness of the firm in the management of human resources, all these questions, however, need the provision of cost measurement and value of human resources. The study, on the other hand, has reviewed in brief the experience of two firms, one of which is an industrial firm and the other is insurance firm, in respect of how the two firms apply the methods of measurement of cost and value of human. As referred by the study, the proposed measurements are such internal organizing instruments set up to help in the management of human resources. The study then provided some guidelines on how to start to develop the measurement for the value of human resources. In addition, the study has focused much on the cost of polarization and selection and recruitment as well as other costs, which can be achieved by recruiting more employees. Nevertheless, salaries and wages as well as other benefits, which would be received by the employees, in addition to the cost of training and development, all these factors have great significance as indicators for the value of the services of human resources in the firm. The study of Herman, (Herman A.Theeke, 2005), which entitled: A human resource accounting transmission: shifting from failure to a future. The study reviews a new model of accounting for human resources called "liability paradigm" as an alternative of assets model. The study has shown how to enter intellectual capital as an amount lends by the employees to the business owner against entering it as human assets. To resolve this matter, the study suggested treating these liabilities as deposits upon demand, or long-term tenancy or contingent liabilities, the realization of which may be affected by future events and circumstances. The study has given weight to the latest treatment, based on the fact that, where the probability of the loss is likely not to be confirmed, and then the assets can be reported as a note connected to the financial statement. Therefore, the suggestions provided by the study are directed towards the resolution of the problem of the equity. In that, the study has given weight to the treatment on the basis of contingent liabilities. Despite the fact that, the issue of contingent liabilities arising as a result of the responsibility of the firm towards the employees is not a new issue. However, the study did not provide any proposal as regards to the issue of evaluation. As regard to the study of Hansson (Bo Hansson, 2005) entitled: "Is it Time to Disclose Information about Human Capital. This study dealt mainly with the issue of disclosure for investments in the training of employees. Accordingly, it has been found that, the lack of disclosing standard information, on which training of the employees can be affected, may conceal from investors such significant and useful information in making investment decisions. This may prove that, investment in training yields significant future earnings. The lack of standard of disclosure for investment in training, on the other hand, may confound the distribution of human capital, in the business market. The study has also suggested that, information about training can be provided within the framework of traditional accounting and it does not necessarily to be a part of the assets in the firm's budget. The study of Indra, (Indra, 2005), entitled:" An Empirical Investigation of Annual Reporting, Trends of Intellectual Capital in Sir Lanka" is an applied study on a random sample including the first thirty firms listed on Colombo Stock Exchange. The study findings have shown that, the benefits and wedges of retirement are the most disclosed information, while the value added by human resources is far less disclosed. This position has sometimes been justified by the difficulty of measurement, and in other times by insignificance of measuring this component. The distinguished study: entitled: "Human Resource Accounting- a New Dimension" (Tiwari Ravindra, 2006), has reviewed a new model for human resources accounting including, two trends, the first of which, adopts the model of (Levy Schwartz), where, the capitalization of the current value of the salaries and wedges expected to be offered to the employees should be effected. The second trend is to capitalize the items of expenditure on training and development of human resources. However, specific method for the entry of these amounts in the accounting records and its regular amortization according to the years of service has been well demonstrated. This method is not without personal judgment in its most parts. This is in addition to the complications to which the author has been the first to admit. He as well, used the method of capitalization of extraordinary revenues for some classes of employees, presuming that these revenues are resulting from talents and skills belong to these categories. The pioneering work, "Human Resources Accounting- a New Method to Measure the Value of Human Resources Services" (Kamal Hassan Gumoa, 2007) has introduced a new proposed method based on the measurement of the value of services provided by the employees through their contribution to the operations of the firm, and how to record this value and modify it from time to time, using information obtained from financial statements of Jordanian firms. Based on said facts, the study has reached a number of findings, of which, the most significant are the following: Human are resources for overall society, and not only for the firm, which gains benefit from them. 
Based on this account, the study recommended the exclusion of the idea of considering the employees as resources belong to the firm and to move towards the calculation of the value of human resources services. The study also recommended disclosing sufficient information about the employees in the annual reports in a consistent formula. The study of Amera Hamed "Accounting for Intellectual Capital and its Effect on Financial Performance of the Firm- A Quantitative Approach" an applied study on a sample of pharmaceutical and mobile firms' managers and business men, (Amera Hamed Elsaid, 2007) in this study, the sample has been tested randomly in which the representation of pharmaceutical and mobile firms and business men has been duly observed. The study has reached the following findings: there is a correlation between the accounting measurement for intellectual capital and the marketing value of the firm. There is an inverse correlation between the rate of separation from labor force and the intellectual capital. There is a correlation between the accounting measurement for intellectual capital and the financial performance. In his in depth study, "Accounting for Intellectual Capital and its Effect on the Value of the Firm - a field study on Khartoum Stock Exchange," Abduelgani (Abduelgani Mahmoud Abdullah Hassan, 2012), has reached the fact that, intangible and intellectual assets in the firm constitute the most and significant part of its capital, particularly, in firms of intensive knowledge. The study findings have shown the existence of a direct correlation between the increase in intellectual capital and the increase in the marketing value of the firm. The study has also revealed that, there is a need for the disclosure of intellectual capital at the heart of the financial statements, in order to rationalize the investment decisions. In his applied study on the listed Egyptian firms, entitled: "Determinants of Accounting Disclosure for Intellectual Capital and its Effect on Financial performance" Magdi (Magdi Mileji, 2013) aimed primarily to identify the affecting determinants on the level of accounting disclosure for intellectual capital. (Characteristics of firm and corporate governance's mechanisms) and the analysis of the effect of the same on the financial performance of the listed Egyptian firms. The study has reached the conclusion that, there is a positive correlation that is statistically significant between the level of accounting disclosure for intellectual capital and the financial performance of the listed Egyptian firms. George and Jeffery in their applied study on a sample of Emirate firms) named: "Voluntary Disclosure for Intellectual Assets and Intellectual Liabilities" (George and Jeffery, 2013), sought to achieve the objective of their study relying upon the analysis of financial reports of (124) public listed Emirate firms, during the years of (2010-2011). The study has reached some findings including the existence of a positive correlation between the disclosures for intellectual capital and structural capital and relational and the return on equity. Salim Bafagir applied study on a sample of Yemeni business firms, entitled: "Measuring the Effect of Intellectual capital and its disclosure on Business Firms' Performance.", (Salim Bafagir, 2014), has found that, there is an increasing interest in intellectual capital from the part of researchers in recent years, which has been reflected in the emergence of several study studies that aimed to discuss this subject. The study has also shown the difficulty that seems to encounter the researchers in identifying and measuring the intellectual capital. Taking into account that, most of the firms do not disclose their intellectual capital, and only satisfy with the disclosure of the value of reputation and intellectual property in sometimes. Said Elsakini, on the other hand, has conducted an applied study on a sample of business firms in the city of Irbid in Jordan, (Said Elsakini, 2015), "Intellectual Capital and Challenges Facing Accountants to measure it". The study has reached many study findings, the most significant of which, are the following: the conceptual framework of accounting lacks the inclusion of fundamental concepts of intellectual capital, which constitutes for the time being, other additional aspects of deficiency in the accounting of theory. This is in one hand, however, most of the components of intellectual capital, on the other hand, are difficult to be represented in a quantitative manner, therefore, the process of evaluating and measuring the same depends mainly on diligence and personal judgment. As a matter of fact, this position may render the information obtained, lacks reliability, since there is no evidence to support it. One important study is that of Suad Gaid, (Suad Gaid, 2016) which entitled: "Measurement and Disclosure for Intellectual Capital and its Role in Increasing the Value of Economic Unit" it is an applied study on southern public firms for cement-Muthana governorate- Algeria. The study has reached the fact that, there is a possibility for economic unit to perform the process of accounting disclosure for human capital by reliance on Intellectual allocations. There is also a possibility of accounting disclosure for human capital in the balance sheet statement of the economic unit. Isam Eltawil in his field study on Palestine Stock Exchange- service sector. (Isam Eltawil, 2018) "The Effect of Accounting Measurement and Disclosure for Intellectual Capital on the Improvement of the Quality of Accounting Information". The study has shown that, there is a correlation between the accounting measurement and disclosure for intellectual capital and the increasing reliability and relevance of financial statements. It is obvious that all previous studies have dealt with the subject of intellectual capital in terms of administrative and accounting perspective. The attempt of these studies is to correlate significantly between the intellectual capital and its various variables. However, the most part attempt to investigate the disclosure and measurement of intellectual capital. Whereas other studies tend to identify the 
effect of intellectual capital on the financial and economic and general performance of the firm. This is in addition to its effect on the marketing value and the improvement of the quality of accounting information and the performance efficiency of the human resources. The remarkable observation in this regard, is that these previous studies do not correlate between the accounting for intellectual capital and its role in the achievement of the human resources value in the firm. This is what the present study seeks to investigate.

\section{Study Problem}

The study problem is how to affect the accounting for intellectual capital with its three components, (human capital, structural capital, relational capital) and its role in the achievement of human resources value in the universities. To put the study problem into effect, the following questions have been raised:

1. Is there any correlation that is statistically significant between the accounting for human capital and the value of human resources in the university at a significant level of $(a=0.05)$ ?

2. Is there any correlation that is statistically significant between the accounting for structural capital and the value of human resources in the university at a significant level of $(a=0.05)$ ?

3. Is there any correlation that is statistically significant between the accounting for relational capital and the value of human resources in the university at a significant level of $(a=0.05)$ ?

Are there any differences of statistical significance between the responses of the sample of individuals at each university on the correlation between the accounting for intellectual capital with its three components, (human capital, structural capital, relational capital) and the value of human resources at a significant level of $(a=0.05)$ ?

\section{Study Objectives}

The study aims to achieve the following:

1. To identify intellectual capital as well as its significance and components.

2. To identify the applied and reliable perspective in measuring intellectual capital.

3. To identify the method used in the disclosure for intellectual capital.

4. To lay down envisage on how to apply accounting for intellectual capital with its three components in the two universities.

To identify the effect of intellectual capital on the value of human resources in the two universities.

\section{Study Significance}

This study significance arises from the fundamental role of intellectual capital in the viability and continuity of firms and the determination of their competitive position in business environment. Based on this, the significance of the determination of the accounting means and methods of the measurement and disclosure for intellectual capital in the financial statements will arise. This is besides, to identify the effect of the same on the value of human resources. One of the most important true increments, this study seeks to add is to introduce a model on how to effect the application of accounting for intellectual capital and its role in the achievement of human resources value in universities. To achieve the study objectives, the following hypothesis have been tested:

1. H01: There is no correlation that is statistically significant between the accounting for human capital and the value of human resources in the university at a significant level of $(a=0.05)$.

2. H02: There is no correlation that is statistically significant between the accounting for structural capital and the value of human resources in the university at a significant level of $(\mathrm{a}=0.05)$.

3. H03: There is no correlation that is statistically significant between the accounting for relational capital and the value of human resources in the university at a significant level of $(a=0.05)$

4. H04: There are no differences of statistical significance between the responses of the sample of individuals at each university on the correlation between the accounting for intellectual capital with its three components, (human capital, structural capital, relational capital) and the value of human resources at a significant level of $(a=0.05)$.

\section{Study Model}

This model has been developed in order to identify the extent to which independent variable affect the dependent variable, as per the following: 


\begin{tabular}{||l|l|}
\hline \multicolumn{1}{|l}{ Independent variable: Accounting for } \\
\hline $\begin{array}{l}\text { Accounting for human capital. } \\
\text { Accounting for }\end{array}$ \\
capital. \\
$\begin{array}{l}\text { Accounting for } \\
\text { capital. }\end{array}$ \\
\hline
\end{tabular}

Dependent variable

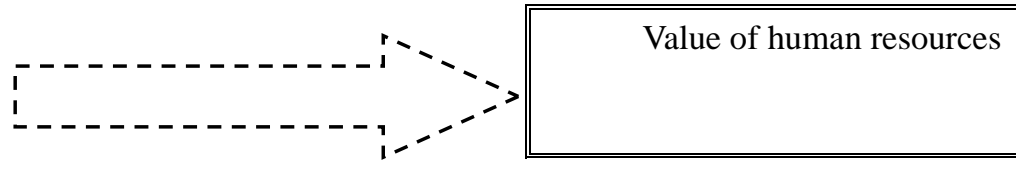

Figure 1. Study Model

Through the above drawn figure, the researchers are of the opinion that, the design of this model has come as result of extensive review of the theoretical literature related to the study subject. This is definitely, will be documented in the theoretical framework of the study, in which a definition and sufficient interpretation of both independent and dependent variables will be given. The mechanisms of the correlation between the independent and dependent variables, relying on the theoretical literature and the findings of the field study in relation to the study subject will also be clarified.

\section{Study Methodology}

To effect the field study, the following study methods have been used:

1. Historical approach: To review prior literature in relation to the study subject.

2. Deductive approach: To determine the study problem and set the hypothesis.

3. Inductive approach: To test the hypothesis.

4. Analytical descriptive approach: To effect field study.

\section{Study Tools}

The study depends largely in the acquisition of the information and data on the primary sources, using the questionnaire technique. This is in addition to the secondary sources, namely, books, references and journals.

\section{Study Limits}

The study limits are represented as follows:

1. Spatial Limits: Dongola University (Faculty of Economics and Administration Sciences) - Abu Dhabi University (academic programs).

2. Temporal Limits: 2018.

3. Human limits: Faculty Members at the two Faculties.

\section{Intellectual capital}

Until now has no precise and agreed upon definition. Yet the same is used to refer to the possession of professional knowledge, experience, skill, good relationships and technological potentials. All these elements collaborate to achieve competitive advantage for the firm by adding a value to key stakeholders. (Hani, 2008). Most firms have appreciated the significant fact that, their real value is based upon something which may be more significant than the physical capital. That is what is called now intellectual capital, which is well represented in the knowledge and quality and innovation and skill of the employees. In addition to the culture of the firm and its organizational operations and patents. This concept, however, expands to include all moral and cultural and mental potentials, available for firms which are working at the level of the community at large. (Elanzi, 2009). Brookings maintains that, intellectual capital is strongly represented in "intangible assets", while, Stewart, on the other hand, and in a more detailed viewpoint, adopts the standpoint that, intellectual capital is "knowledge, information, experience and intellectual property", which can be used in the creation and development of the wealth, (Abas Elshierazi, 1990). From the other point of view, the International Federation of Accountants, (IFAC), has focused much on the element of property and the extent to which it can be transferred into measurable assets. IFAC thus, viewed intellectual capital as an inventory for the assets of the firm, which are based on knowledge. As for the Canadian Chartered Institute of Management Accountants, (CIMA), intellectual capital is represented in "intangible knowledge-based assets owned by the firm, which are expected to achieve continuous future benefits", and this may include technological and innovative abilities as well as administrative 
and consultative expertise. On the other side, Shao, sees intellectual capital as "intangible assets relating to the thought on which the firm is focusing or the absolute gap between the marketing value and the book value of the firm"(Yousef, 2005) The International Accounting Standard N0. 38 defines (intangible assets), as "intangible asset is an identifiable non-monetary asset without physical substance, this assets may be retained to be used in the production or to provide commodities or services or lease for others or for administrative purposes (Adel and Ahmad , 2003).

What has been quoted earlier of various definitions by the researchers is that, there is no agreement on the definition of intellectual capital. However, there is a substantial agreement on their definitions of intellectual capital represented in obtaining such a type of knowledge that could lead to achieve real value. In the same context, the researchers have defined intellectual capital as " a constantly renewable concept due to ever-changing surrounding environment of the overall segments of the firm, starting from the integration of the skills and expertise of the employees up to the distinction in the treatment of the firms importers and finally, the quality of the commodity and service rendered to the costumers. A position, in which the firm may be able to gain competitive advantage and enhance the corporate governance. Thereby, the value of human resources will be raised and eventually, the value of the firm will be locally and internationally raised.

\section{Significance of Intellectual capital:}

The significance of intellectual capital rises from the fact that it represents per se competitive advantages for the firm by paying particular attention to its human resources. In this context, firms nowadays compete effectively based on what they gain of knowledge and information and skills. Thus, interest in intellectual capital deemed inevitable issue determined by the nature of the contemporary scientific and technological challenge. There are of course, numerous benefits that any firm might be able to gain if it has more interest in the intellectual capital. This is because such interest will definitely lead to increase the innovative ability and surprise and attract customers and enhance their allegiance. The significance of intellectual capital arises as well, from the enhancement of the competition in time by providing more new and developed products. The significance of the intellectual capital stems also from the ability to minimize the period between each innovation and that which pursues it. This is in addition to the cost reduction and the improvement of the productivity and the enhancement of the competitive ability, in order to sale the products with competitive prices. (Mari, 2006).

The researchers are in the opinion that, in light of such great significance of the intellectual capital and the volume of the directed investments or that which should be directed towards its components and the scarcity of the resources which has become one of the most significant determinants, in addition to the severe competition which is considered as the basic characteristic of the economic environment. It is inevitable to direct the attention of the different firms to appreciate the significance of the intellectual capital and the necessity to develop the same, since it deems to be the master key to resolve any problem and the powerful leader to manage other resources. This is in order to guarantee the continuity of the ability of these firms to create added value to their human resources, and this in turn will add a real value to the firm and create a powerful competitive position.

\section{Intellectual Capital Components:}

Researchers and thinkers as well as students have introduced various conceptions of intellectual capital and its components, but they disagreed in their visions on those components. However, these following three divisions have been adopted as dimensions of intellectual capital:

1. Human Capital: most study studies have referred to human capital as "a set of accumulative knowledge, skills and experiences that lead to leadership skills and high abilities to solve problems and make rational decisions in the context of feverish competition between different sectors. It is the competitive assets that undertake the process of creative development, which depends on the innovation and renovation, which deemed the clue to remain in an ever-changing business environment.

This outcome will reflect the ability of the firm to manage its tangible and intangible assets in order to build a knowledge of a rooted value and culture that focuses on the investment in human minds and accumulative knowledge to achieve competitive priorities and thus to create additional value which leads to excellence. Perhaps employees individuals are those who create the wealth based on the knowledge and skills they have acquired through their practical interactions with overall elements and variables that enhance them to gain more knowledge and abilities that make them either gifted or distinguished and are able to achieve good results and turn the attention to them as an asset in which investment can be effected and the benefit of which can be maximized (Koha, n, 2014). 
2. Structural Capital: Structural capital is the backbone of the firm, which includes the infrastructure that supports human capital. Structural capital thus includes information systems and ownership of database, organizational charts, operations manual, laboratories, market intelligence information and intellectual property assets that is to say, (trade names and patent) knowledge of (Know-How). In order to get, maintain, transfer and manage knowledge in a high efficiency not only to create new value for shareholders, but to create a sustainable competitive advantage. What is more important, is to achieve organizational excellence (Bishtawi and Bani Taha 2014)

3. Relational Capital: it is also called the capital of clients or customers, this term, however, includes all matters relating to the firm and its external relations with customers, suppliers, government agencies, investors, strategic alliances and distribution channels. In addition to the value that comes from this relationship and the degree of allegiance and satisfaction with the services and products rendered by the firm in order to satisfy their needs and to continuously look forward to sharing with them what they need (Elhilali, 2011).

\section{Approach of Accounting for Intellectual Capital:}

The approach of accounting for intellectual capital includes two basic elements dimensions, namely: the use of the methods of accounting for intellectual capital, which achieve internal and external strategic objectives of the firm. This is besides the use of measurement and disclosure for intellectual capital in measuring the behavior of the different resources (intellectual, material and monetary) to achieve the value.

\section{The following is more elaboration of these dimensions as follows:}

First: Methods of accounting for intellectual capital: According to the concept of the value, which is the usefulness and benefit and desirability, to determine the nature of a method for the measurement and evaluation, requires to identify the subject of measurement and evaluation (intellectual capital), and to classify the criteria of the different methods of measurement and evaluation. In like manner, it requires a framework for the measurement and evaluation according to the criteria of classification. The criteria for the classification of the methods of accounting for intellectual capital include four criteria, one of which applies to any of these methods (Mari, 2006), as per the following:

1. Possibility of expressing the value of intellectual capital in monetary form. The methods, to which the monetary standard applies, are the methods and approaches of financial evaluation of intellectual capital.

2. Possibility of using non-monetary standard for the value of intellectual capital expressed in a quantitative manner. The methods, to which the quantitative standard applies, are called the methods and approaches to measure the value of intellectual capital.

3. Utilization of personal judgment of who undertakes the evaluation in the case of impossibility of using the quantitative standard. The methods, to which the personal judgment applies, are called the methods and approaches of estimating the value of intellectual capital.

4. Utilization of standard scope for the elements of intellectual capital in case of impossibility to apply any of the three preceding standards. The methods, to which the said standard applies, are called the methods and approaches to measure the intellectual capital.

Second: Concept and methods of measurement of accounting for intellectual capital: Measurement is defined as: "expression of aspects and characteristics of a particular field using symbols and weights and numbers in accordance with specific rules" (Ayman Abdullah 2016,). The measurement of intellectual capital as well, refers to "a group of follow-up procedures to determine the extent to which certain characteristics are available in the person and to judge the possibility of having specific functional skills and activities" (ELanzi, 2001). In respect of the methods of accounting measurement of intellectual capital, Skyrme, has determined three principal motivations for the managers to measure intangible assets and knowledge assets in their firms. These motivations can be summarized as follows: the measurement provides a basis for the evaluation of the firm by focusing on the assets. The measurement motivates and urges the management to focus on what is significant, for instance, the activity and action. The measurement may also be used as a basis for the justification of investment in the activities of knowledge management by focusing on utility or benefit (Skyrme, D, 1997).

The methods used in measuring intellectual capital can be classified into four categories as follows (Zahra Ahmed, 2013):

1. Descriptive measures: these measures focus on the identification of the attributes and characteristics of intellectual capital. They also set up to carry out a survey on the opinions and trends of indirect effect on the performance of knowledge operations in order to achieve the required outputs. The 
process of measuring these models is performed based on personal experience and judgment of those who carry out the study.

2. Intellectual property measures: These measures focus on the determination of the value of intellectual capital, including its basic components (human, structural, relational). They work as well, to transfer the intangible intellectual property in the different sections of the firm into the forms of intellectual property in order to be more specific and easy to use.

3. Market value measures: These measures focus on the difference between the book value and market value of the firm. They are likely depend on accounting basis and principles, such as the market value and book value as well as the intangible calculated value

4. Return on assets measures: These measures depend on the calculation of return on assets (ROA) by the division of the firm's pre-tax returns on tangible assets. These returns will subsequently, be compared with the average of industry at large, within which the activity of the firm falls. Therefore, any increase over the industry average deemed as a return of the firm's knowledge, such as intangible value and intellectual capital gains.

Third: Concept and methods of disclosure for intellectual capital: Disclosure can be defined as a "tool to provide sufficient information of intellectual capital of the firm for the stakeholders in an objective and an appropriate and a timely manner. This is of course one of the objectives of the accounting for human resources, which represents the actual translation of the outputs of the process of identification and measurement. Based on these outputs, the effectiveness and accuracy of the decisions made will be determined by overall stakeholders".

There are many methods in which intellectual capital is disclosed as follows (Abbas Shirazi, 1990):

1. Method of disclosure within the annual management report: Flamholz has pointed out that the annual management report usually includes information on investment in human knowledge assets, which represents the information of expenditure on these resources during the current fiscal year.

2. Method of disclosure in additional financial statements: in accordance with this method, additional financial statements are prepared together with the basic financial statements, which include sufficient and adequate information on the expenses paid by the economic unit for the development of intellectual capital in its all three types (human, structural, relational), in a manner that makes the unit achieves future benefits, which help external users to make decisions.

3. Method of disclosure in the financial statements: in accordance with this method, the disclosure of the value of intellectual capital in the final financial statements of the economic unit is performed. This including the disclosure of cash disbursements of any unit of investment in intellectual capital, in addition to the actual value of the same, (Tijani Ahmad, 2013).

This is however, is the most appropriate method in the presentation and disclosure for knowledge assets and intellectual property. The reason is that; these assets are fixed (intangible) assets. According to the accounting standards these assets can be included in the item of tangible assets, ensuing the fixed assets item, since they are characterized as having materiality by providing the financial statements users with the necessary and significant information. This is in addition to their role in the performance evaluation of human resources and the firm as a whole.

Based on the referred to above argument, the researchers are in the opinion that, the, accounting measurement and disclosure for intellectual capital in the financial statements of the firm increases the assets and enhances the value of human resources in the firm.

\section{Value of Human Resource}

Human beings have been regarded as a significant resource and have a significant and effective role in effecting the success of the firm. The value of human resources is well represented in the value of human assets as intellectual capital, which includes human capital, structural capital and relational capital, through additions and changes to it from year to year, which significantly affects that value. Disclosure for information relating to this resource is considered useful for the purposes of decisions making. Many researchers have attempted to find out such effective means by which an objective statement about the economic value of human resources can be made. In addition to disclose a specific value for these resources and make a statement of changes to their value from year to year and facilitate and improve the management of these resources in an effective and efficient manner. 
Some firms have disclosed the value of their human resources in the financial statements. Considering the fact that, most firms have become interested in how to determine the values that reflect the knowledge and skills of the employees for the purposes of financial reporting, where, the technological and economic developments have led to the contentment of the different firms that, the level of knowledge assets provides an indicator of the possibilities of future profitability. Given that, there is a widespread belief among many researchers that, disclosure of a value for human assets in the public budget, constitutes a dangerous and unsecured operation since it lacks stability. This is besides, the difficulties of measurement. In general terms, human resources in the concept of economists are a source of revenue that can be measured by measuring the current value of the expected commodities and services as a result of having been used in the firm and interacted with other income sources.

The cost of human resources also represents an objective basis in the wealth achievement. According to the capitalist economic theory, the factors of production and machinery are the raw materials, production requirements, machinery, equipment, fixed assets, capital and the regulation. The focus here is on the role of the regulator, in particular, the owner and the management in wealth achievement. This proves that, human resources strongly represent this factor. By the interaction between said four factors, the creation of the value and wealth increase are effected. The economic theory of Marxism, on the other hand, depends basically on the work factor, particularly the living work factor. This is, however, meant to reflect the efforts made by employees in the economic unit, which is deemed to be the substantive basis for value creation, particularly the investment value.

Besides the significant role of human resources in the process of production, they have also a primary role in the administrative and organizational process, The human element indeed has a decisive role in the management that characterized by efficiency and good governance as well as effective performance. This position would consequently, lead to maximize the wealth of a firm that enjoys perfect administrative and technical human resources, compared to another firm, which lacks such efficient resources (Modthir Hassan Salim,2017).

Generally, the elements of human resources cost can be limited to the acquisition of human resources cost, including the cost of polarization, selection, recruitment, contracting, placement and auxiliary services such as health insurance, transportation and work uniform, etc. This is besides the cost of human resources learning, which includes, the cost of training, mentoring, promotion and improvement. In the same context, other numerous types of costs may also be considered, that is to say, the replacement of human resources cost and the cost of the termination of the service as well as the cost of social security services, and the cost of alternative and loss opportunity, (Kamal Elnaqib, 2010).

\section{Measurement of Human Resources Values:}

Accounting literature demonstrates multiple methods to measure the human resources value, which are mainly concentrated on two basic perspectives namely, cost and economic value, where, the first perspective depends on the realized cost in the process of polarization and selection and recruitment of the employees or alternative and opportunity cost. The second perspective, on the other side, depends largely on the discounted future returns.

\section{Overview of Accounting for human Resource Value:}

Throughout ancient times, accounting thought has much focused only on physical capital, which is represented in the purchase of financial assets and hence to register the ownership of these assets in the accounting books and give the same a financial value. Consequently, there has been no interest in intellectual capital which is represented in intellectual assets. However, modern accounting in the past century has been able to get out of this garment by recognizing these intellectual assets starting with structural capital and relational capital (cliental). Recently, accounting thought has focused its attention on the human capital and hence, move to exploit the services of these human resources and not to possess them. As a matter of fact, accounting has been rendered by this position as a tool in which the social, economic and philosophical impacts of the society are reflected. (Ayman Abdullah, 2017). The researchers generally viewed the accounting value as the most closest to the reality of finding out the economic value of the firm, since it depends on the net assets of economic unit. This value is applicable in overall economic firms, whether, publicly shared firms or not.

\section{Applied Study}

The study depend on the questionnaire data in effecting the procedures of the applied study. A questionnaire form has been distributed to the faculty members as representatives of a non-random (purposive) sample for each of the Faculty of Economics and Administration Sciences at the University of Dongola and the academic programs at Abu Dhabi University. 


\section{Study Community \& Sample:}

The study community is represented in the Dongola University in the Sudan and the Abu Dhabi University in the United Arab Emirates. To put the applied study into effect the researchers have chosen out a non-random (purposive) sample of said community based on their knowledge that, this sample is properly represent the study community, which includes the following faculties:

1. Faculty of Economics and Administration Sciences - Dongola University.

2. Academic programs -Abu Dhabi University.

The size of the sample has been determined to include 40 faculty members, where, the size of the sample deems appropriate for the most part of researches if it is larger than (30) and less than 500. (Ayman Abdallah, et all, 2017).

\section{Study Tool:}

For the purposes of study data collection a questionnaire form has been designed on Likert scale, (five-point scaling), to identify the role of accounting for intellectual capital in the achievement of the value of human resources in the universities. The questionnaire form consists of following parts and variables:

First Section: is represented in the independent variable, which is the interest in accounting for intellectual capital in the university, which includes, three Sub-dimensions represented in (Accounting for human capital, accounting for structural capital, accounting for relational capital).

Second Section: It is well represented in the dependent variable, which is the value of human resources at the university.

\section{Methods of Statistical Treatment:}

The researchers will follow the method of statistical analysis, using the Statistical Packages for the Social Science program (SPSS), with a view to reaching significant findings and recommendations on the role of accounting for intellectual capital in the achievement of the value of human resources in the universities.

To answer the study questions and test the study hypothesis, some of the methods of the descriptive statistics and analytical statistics will be used as follows: (p Waracck, B, 2001).

1. Measurements of Descriptive Statistics, using the arithmetic mean and standard deviation.

2. Measurements of Analytical Statistics:

i. Cornbrash's alpha test: to determine the stability of the questionnaire's statements.

ii. Pearson Correlation Coefficient: to verify the credibility of the questionnaire's statements.

iii. Multiple Linear Regression Analysis: to test the effect of independent variables on the dependent variable.

iv. Dependent variable.

v. Two-sample T-test: to test the average of two samples.

vi. One Way Anova: to find the differences between the two samples.

\section{Study Tool Stability:}

To test the internal consistency the stability coefficient has been calculated according to Cronbach's alpha coefficient to verify the questionnaire's statements. This is in addition to identify the overall variables dimensions as explained below:

Table 1. Results of Study Tool Stability: (internal consistency of questionnaire's statements

\begin{tabular}{|c|c|c|}
\hline Variables and Dimensions & $\begin{array}{l}\text { Number of } \\
\text { Statements }\end{array}$ & $\begin{array}{c}\text { Cronbach's alpha), Stability } \\
\text { Coefficient }\end{array}$ \\
\hline 1. Interest in accounting for intellectual capital. & 19 & 0.95 \\
\hline - Accounting for human capital & 6 & 0.79 \\
\hline - Accounting for structural capital & 7 & 0.81 \\
\hline - Accounting for Relational Capital & 6 & 0.80 \\
\hline 2. Value of human resources in the universities & 6 & 0.85 \\
\hline Total tool & 24 & 0.95 \\
\hline
\end{tabular}


Table (1) results clearly show that, all validity and reliability coefficients of the responses of the individuals of the survey sample to the study variables and dimensions are high, since they are accepted stability rates for the purposes of scientific study and statistical analysis.

\section{Descriptive Analysis Results of Study variables:}

1. Results of Descriptive statistical analysis of the independent variable (interest in accounting for intellectual capital):

Table (2) demonstrates the results of descriptive statistical analysis of the independent variable (interest in accounting for intellectual capital) as follows:

Table 2. Results of descriptive statistical analysis of independent variable- interest in accounting for intellectual capital

\begin{tabular}{|c|c|c|c|}
\hline Statement & $\begin{array}{l}\text { Arithmetic } \\
\text { Mean }\end{array}$ & $\begin{array}{l}\text { Standard } \\
\text { Deviation }\end{array}$ & $\begin{array}{l}\text { Degree of } \\
\text { Agreement }\end{array}$ \\
\hline Interest in accounting for intellectual capital : & 4.0999 & 0.29755 & High \\
\hline A. Accounting for Human Capital : & 4.0988 & 0.55181 & High \\
\hline $\begin{array}{l}\text { 1. The university administration is interested in recruiting high-level } \\
\text { competencies to work therein. }\end{array}$ & 40.9656 & 1.12600 & High \\
\hline $\begin{array}{l}\text { 2. The university maintains faculty members of scientific competence to } \\
\text { improve the learning process. }\end{array}$ & 3.7557 & 0.99815 & Medium \\
\hline $\begin{array}{l}\text { 3. The university is interested in the accounting measurement of the } \\
\text { programs and development of employees' training. }\end{array}$ & 3.2277 & 0.97500 & Medium \\
\hline $\begin{array}{l}\text { 4. Different methods of accounting measurement are used in measuring } \\
\text { what enhances the skills of university faculty members. }\end{array}$ & 4.5242 & 0.88934 & High \\
\hline $\begin{array}{l}\text { 5. Disclosure for human capital in financial statements provides relevant } \\
\text { information for the users. }\end{array}$ & 4.5634 & 0.98600 & High \\
\hline $\begin{array}{l}\text { 6. Accounting measurement and disclosure for human resources used at } \\
\text { the university reflects more relevance and reliability of financial } \\
\text { statements. }\end{array}$ & 4.3314 & 0.49655 & High \\
\hline B. Accounting for structural capital : & 4. 4499 & 0.98713 & High \\
\hline $\begin{array}{l}\text { 7. The university possesses a high ability to make benefit from its } \\
\text { experiences to develop the levels of development and learning. }\end{array}$ & 4. 4011 & 0.90201 & High \\
\hline $\begin{array}{l}\text { 8. Organizational relations between the faculties of the university and its } \\
\text { programs and scientific departments are characterized by cooperation, } \\
\text { integration and exchange of experiences. }\end{array}$ & 3.4134 & 0.91908 & Medium \\
\hline $\begin{array}{l}\text { 9. The method of the work in the university and its faculties and } \\
\text { programs enjoys the spirit of one team. }\end{array}$ & 4.9110 & 0.58234 & High \\
\hline $\begin{array}{l}\text { 10.The university enjoys advanced information systems and databases } \\
\text { systems, which distinguish it from other universities. }\end{array}$ & 4.4023 & 0.85567 & High \\
\hline $\begin{array}{l}\text { 11. Measurement and accounting disclosure for training and educational } \\
\text { services is performed at the university. }\end{array}$ & 3.6789 & 0.93112 & Average \\
\hline $\begin{array}{l}\text { 12. Measurement and accounting disclosure for the values and } \\
\text { principles and business standards of the firm helps motivate human } \\
\text { resources }\end{array}$ & 4.8814 & 0.92899 & High \\
\hline $\begin{array}{l}\text { 13. Accounting measurement and disclosure for structural capital } \\
\text { reflects more relevance and reliability of financial statements. }\end{array}$ & 4.8015 & 0.88115 & High \\
\hline C. Accounting for Relational Capital : & 4. 9911 & 0.88775 & High \\
\hline $\begin{array}{l}14 \text {.The university is characterized by having broad and developed } \\
\text { relations with government bodies and private sector firms. }\end{array}$ & 4. 9080 & 1.52166 & High \\
\hline $\begin{array}{l}\text { 15. The university has some good relations in the area of cooperation } \\
\text { and coordination with national and international educational and } \\
\text { training institutions, which enhances its reputation in creativity and } \\
\text { excellence. }\end{array}$ & 3.4951 & 0.88701 & Medium \\
\hline $\begin{array}{l}\text { 16. The university provides programs of support and assistance to the } \\
\text { faculty members in order to maintain creativity and excellence. }\end{array}$ & 4.4070 & 0.90811 & High \\
\hline $\begin{array}{l}\text { 17. Accounting measurement and disclosure for the relations of the } \\
\text { university with other external parties is adequately performed. }\end{array}$ & 3.4560 & 0.87322 & Medium \\
\hline $\begin{array}{l}\text { 18. Disclosure for relational capital in financial reporting provides } \\
\text { relevant information for the users. }\end{array}$ & 4.7012 & 0.74523 & High \\
\hline $\begin{array}{l}\text { 19. Accounting measurement and disclosure for relational capital } \\
\text { reflects more objectivity and reliability in the financial statements. }\end{array}$ & 4.3001 & 0.73245 & High \\
\hline
\end{tabular}


Based on table (2) data that the trends of study sample has been positive towards all statements, which measure the independent variable with its sub-variables and with high dimensions as follows:

A. Arithmetic mean and standard deviation of accounting for human capital have reached (4.0 988) and (0.5 5181) respectively. This however, reflects the ability of the university (study sample) in the attention to the accounting for human capital.

B. Arithmetic mean and standard deviation of accounting for structural capital have reached (4.4499) and (0.98713) respectively. This however, reflects the ability of the university (study sample) in the attention to the accounting for structural capital.

C. Arithmetic mean and standard deviation of accounting for relational capital have reached (4.9911) and $(0.88775)$ respectively. This however, reflects the ability of the university (study sample) in the attention to the accounting for relational capital.

Based on the referred to above facts, the researchers maintain that, the arithmetic mean and standard deviation of the variable of the interest in accounting for intellectual capital at the university have reached (4.0999) and (0.29755) respectively, which reflects the extent of the management of these universities in having interest in this trend.

2. Results of descriptive statistical analysis of the dependent variable (value of human resources at the universities):

Table (3) reflects the results of the descriptive statistical analysis of the dependent variable, (value of human resources at the universities) as follows:

Table 3. Results of statistical analysis of the dependent variable. The value of human resources at the universities

\begin{tabular}{|l|l|l|l|}
\hline Statement & $\begin{array}{l}\text { Arithmetic } \\
\text { Mean }\end{array}$ & $\begin{array}{l}\text { Standard } \\
\text { Deviation }\end{array}$ & $\begin{array}{l}\text { Degree of } \\
\text { Agreement }\end{array}$ \\
\hline Value of human resources at the university : & 4.3915 & 0.80113 & High \\
\hline $\begin{array}{l}\text { 20. The university works to determine the value of its human } \\
\text { resources. }\end{array}$ & 3.2012 & 0.80344 & Medium \\
\hline $\begin{array}{l}\text { 21. The university is interested in the improvement of what is existed } \\
\text { of training and educational services. }\end{array}$ & 4.3611 & 0.87123 & High \\
\hline $\begin{array}{l}\text { 22. The faculty member feels a high degree of job security at the } \\
\text { university. }\end{array}$ & 3.3113 & 0.90120 & Medium \\
\hline $\begin{array}{l}\text { 23. The university is interested in improving the value of its human } \\
\text { resources. }\end{array}$ & 4.1657 & 0.53146 & High \\
\hline $\begin{array}{l}\text { 24. The university provides the best technological means for the } \\
\text { faculty members and administrators to provide the best educational } \\
\text { and training services. }\end{array}$ & 3.2839 & 0.91324 & High \\
\hline 25. There is a value of human resource at the university. & 3.6647 & 0.91989 & High \\
\hline
\end{tabular}

Based on table (3) data the study mention the following: The majority of the target sample of the two universities in question is highly agree that, there is a value for human resources in the university, where the arithmetic mean and standard deviation of all questions of the variable of the value of human resources in the university have reached (4. 3915)and (0.80113) respectively.

\section{Study Hypothesis Test:}

1. First hypothesis:

Table 4. Results of simple linear regression analysis to measure the correlation between the accounting for human capital and the value of human resources in universities

\begin{tabular}{|l|l|l|l|l|}
\hline Statement & $\begin{array}{l}\text { Regression } \\
\text { coefficients }\end{array}$ & Test ( T) & $\begin{array}{l}\text { Probability } \\
\text { Value (Sig) }\end{array}$ & Interpretation \\
\hline$\left(\hat{B}_{0}\right)$ & 1.8900 & 9.101 & 0.000 & Significant. \\
\hline$\left(\hat{B}_{1}\right)$ & 0.489 & 9.301 & 0.000 & Significant. \\
\hline Accounting for human capital & 0.230 & 3.511 & 0.000 & Significant. \\
\hline
\end{tabular}




\begin{tabular}{|l|l|l|l|l|}
\hline Value of human resources in the universities. & 0.316 & 4.416 & 0.000 & Significant. \\
\hline Correlation coefficient $(R)$. & 0.68 & & \\
\hline Coefficient of determination $\left(R^{2}\right)$. & 0.39 & & \\
\hline Test (F). & 88.645 & The sample is significant. \\
\hline
\end{tabular}

Based on table (4) data, the study mention the following:

1. The results of the estimation have shown a strong direct correlation between the accounting for human capital as an independent variable and the value of human resources in the universities as a dependent variable, where,

the simple correlation coefficient is $(0.68)(R)$.

2. The value of the coefficient of determination is $(0.39)^{6}\left(R^{2}\right)$. This value, however, indicates that, accounting for human capital as an independent variable contributes with (39\%) to the human resources value in the universities (dependent variable).

3. The simple regression model is significant, where, the value of the $(F)$ test is $(88.645)$, which is at a significant level of (0.000).

4. (1.8 900): Accounting for human capital at the value of human resources in the universities equals zero.

5. (0.4 89): this indicates that accounting for human capital is a one unit at the value of the human resources in the universities by $48 \%$.

Based on said facts, the study inferred that the hypothesis (null hypothesis H01: $\mu$ ), which provides that: " There is no any correlation that is statistically significant between the accounting for human capital and the value of human resources at the university at a significant level $\mathrm{a}=0.05$ ). " has not been proved. Therefore, the

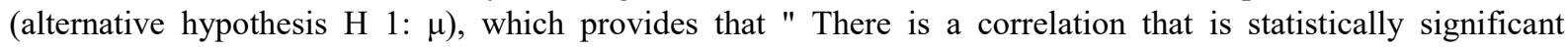
between the accounting for human capital and the value of human resources at the university at a significant level of $(\mathrm{a}=0.05)$ ", has been proved, which is the correct hypothesis.

This result, however, is consistent with the study of Hansson, (Bo Hansson, 2005) and the study of Tiwari, (Tiwari Ravidra, 2006) as well as the study of Abdelgani (Abdelgani Mahmoud Abdallah Hassan, 2012). The said finding is also consistent with the study of George \& Jeffery (George \& Jeffery, 2013) and the study of Saud Jaid (Saud Jaid, 2016) in addition to the study Esam Eltawil (Esam Eltawil, 2018).

The current study findings, on the other hand, are not in agreement with the results of both studies of Indra (Indra, 2005) and Saeed (Saeed Elsakini, 2015).

\section{Second hypothesis:}

Table 5. Results of simple linear regression analysis to measure the correlation between the accounting for structural capital and the value of human resources in the universities

\begin{tabular}{|l|l|l|l|l|}
\hline Statement & $\begin{array}{l}\text { Regression } \\
\text { coefficients }\end{array}$ & E test $(\mathrm{t})$ & $\begin{array}{l}\text { Probability } \\
\text { Value (Sig) }\end{array}$ & Interpretation \\
\hline$\left(\hat{B}_{0}\right)$ & 1.8001 & 9.181 & 0.000 & Significant \\
\hline$\left.\hat{B}_{1}\right)$ & 0.471 & 9.291 & 0.000 & Significant \\
\hline Accounting for structural capital & 0.220 & 3.766 & 0.000 & Significant \\
\hline $\begin{array}{l}\text { Value of human resources in the } \\
\text { university. }\end{array}$ & 0.320 & 4.155 & 0.000 & Significant \\
\hline
\end{tabular}




\begin{tabular}{|c|l|l|}
\hline Correlation coefficient $(R)$. & 0.67 & \\
\hline Coefficient of determination $\left(R^{2}\right)$. & 0.38 & \\
\hline F Test & 88.123 & The sample is significant \\
\hline
\end{tabular}

Based on table (5) data, the study mention the following:

1. The results of the estimation have shown a strong direct correlation between the accounting for structural capital as an independent variable and the value of human resources in the universities as a dependent variable, where, the simple correlation coefficient is $(0.67)$.

2. The value of the coefficient of determination is $(0.38) \cdot\left(R^{2}\right)$. This vale, however, indicates that, accounting for structural capital as an independent variable contributes with (38\%) to the human resources value in the universities (dependent variable).

3. The simple regression model is significant, where, the value of the (F) test is (88. 123), which is at a significant level of (.000).

4. . (1.8811): Accounting for structural capital at the value of human resources in the universities equals zero.

5. (0.471): this indicates that accounting for structural capital is a one unit at the value of the human resources in the universities by $47 \%$.

Based on table (4) data, the study mention the following: The study inferred that the hypothesis (null hypothesis H02: $\mu$ ), which provides that: " There is no any correlation that is statistically significant between the accounting for structural capital and the value of human resources at the university at a significant level of $(a=0.05)$ ", has not been proved. Therefore, the (alternative hypothesis H 1: $\mu$ ), which provides that " There is a correlation that is statistically significant between the accounting for structural capital and the value of human resources at the university at a significant level of $(a=0.05)$ ", has been proved, which is the correct hypothesis.

This result, however, is consistent with the study of Abdelgani (Abdelgani Mahmoud Abdallah Hassan, 2012) and the study of George \& Jeffery (George \& Jeffery, 2013) in addition to the study of Esam Eltawil, (Esam Eltawil, 2018).

The current study findings, on the other hand, are not in agreement with the findings of both studies of Indra ( Indra, 2005) and Saeed (Saeed Elsakini, 2015.

\section{Third hypothesis:}

Table 6. Results of simple linear regression analysis to measure the correlation between the accounting for relational capital and the value of human resources in the universities

\begin{tabular}{|c|c|c|c|c|}
\hline Statement & $\begin{array}{l}\text { Regression } \\
\text { coefficients }\end{array}$ & $\mathrm{T}$ test & $\begin{array}{l}\text { Probability } \\
\text { Value (Sig) }\end{array}$ & Interpretation \\
\hline$\left(\hat{B}_{0}\right)$ & 1. 8811 & 9.811 & 0.000 & Significant \\
\hline$\left.\hat{B}_{1}\right)$ & 0.469 & 9.302 & 0.000 & Significant \\
\hline Accounting for relational capital & 0.299 & 3.788 & 0.000 & Significant \\
\hline $\begin{array}{l}\text { Value of human resources in the } \\
\text { university. }\end{array}$ & 0.320 & 4315 & 0.000 & Significant \\
\hline Correlation coefficient ( $R \quad$ ) & 0.63 & & & \\
\hline coefficient of determination ( $R^{2}$ ) & 0.35 & & & \\
\hline F Test & 88.301 & The san & gnificant & \\
\hline
\end{tabular}


Based on table (6) data, the study mention the following:

1. The results of the estimation have shown a strong direct correlation between the accounting for relational capital as an independent variable and the value of human resources in the universities as a dependent variable, where, the simple correlation coefficient is $(0.63)$.

2. The value of the coefficient of determination is $(0.35)^{6}\left(R^{2}\right)$. This value however, indicates that, accounting for relational capital as an independent variable contributes with (35\%) to the human resources value in the universities (dependent variable).

3. The simple regression model is significant, where, the value of the (F) test is (85.301), which is at a significant level of (.000).

4. . (1.8811): Average accounting for relational capital at the value of human resources in universities equals zero.

5. (0.469): this indicates that accounting for relational capital is a one unit at the value of the human resources in the universities by $48 \%$.

Based on said facts, the study inferred that the hypothesis (null hypothesis H03: $\mu$ ), which provides that: " There is no any correlation that is statistically significant between the accounting for relational capital and the value of human resources at the university at a significant level of $(\mathrm{a}=0.05)$ ", has not been proved. Therefore, the

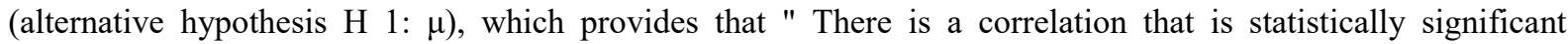
between the accounting for relational capital and the value of human resources at the university at a significant level of $(\mathrm{a}=0.05)$ ", has been proved, which is the correct hypothesis.

This result, however, is consistent with the study of Abdelhadi (Abdelgani Mahmoud Abdallah Hassan, 2012) and the study of George \& Jeffery (George \& Jeffery, 2013) in addition to the study of (Esam Eltawil, ((Esam Eltawil, 2018).

The current study findings, on the other hand, are not in agreement with the findings of both studies of Indra ( Indra, 2005 ) and Saeed (Saeed Elsakini, 2015.

Fourth hypothesis:

There are no differences of statistical significance between the responses of the sample of individuals at each university on the correlation between the accounting for intellectual capital with its three components, (human capital, structural capital, relational capital) and the value of human resources at a significant level of $(\mathrm{a}=$ $0.05)$. This is can be verified by the following:

Table 7. Results of One Way Anova analysis of the statements $(25,24,22,19,16,13,12,6,4,1)$ of the tables in the figures (3.2) to find out the statistical differences between the two samples

\begin{tabular}{|c|c|c|c|c|c|c|}
\hline Statements & $\begin{array}{l}\text { Source of } \\
\text { Variance }\end{array}$ & $\begin{array}{l}\text { Total of } \\
\text { squares }\end{array}$ & $\begin{array}{l}\text { Degree of } \\
\text { freedom }\end{array}$ & $\begin{array}{l}\text { Average } \\
\text { squares }\end{array}$ & $\begin{array}{l}\text { Value of } \\
\mathrm{F}\end{array}$ & $\begin{array}{l}\text { Level } \\
\text { of significa } \\
\text { nce }\end{array}$ \\
\hline \multirow{3}{*}{$\begin{array}{l}\text { Statements }(25,24,22 \\
, 19,16,13,12,6,4,1) \\
\text { Of tables in figures } \\
(3.2)\end{array}$} & $\begin{array}{l}\text { Between the } \\
\text { two samples }\end{array}$ & 4.919 & 4 & 1.401 & \multirow[t]{3}{*}{5.41} & \multirow[t]{3}{*}{0.321} \\
\hline & $\begin{array}{l}\text { Inside the two } \\
\text { samples }\end{array}$ & 22.155 & 86 & 0.239 & & \\
\hline & Total & 27.074 & 90 & & & \\
\hline
\end{tabular}

Based on table (7) data, the study mention the following:

The results of One Way Anova for the aforementioned statements show a value of a level of a significance of $(0.321)$, which is greater than the value of the significant level of $(0.05)$. This indicates that, the (null hypothesis H04: $\mu$ ), which provides that: " There are no differences of statistical significance between the responses of the individuals of the sample at each university on the correlation between the accounting for intellectual capital with its three components, (human capital, structural capital, relational capital) and the value 
of human resources at a significant level of $(\mathrm{a}=0.05)$, has been proved.

\section{Findings and Recommendations}

\section{First: Study Findings:} the following:

Based on this account, the study has reached a number of findings, of which, the most significant are

1. The study findings have shown that the management of the two universities have a particular interest in the recruitment of faculty members who enjoy high levels of qualifications.

2. The study findings have proved that, most of the three variables of accounting for intellectual capital (accounting for human capital, accounting for structural capital, accounting for the relational capital) in the two universities have obtained a high degree of agreement among the individual of the study sample.

3. The study findings have revealed that most of the targeted sample of the two universities in question is highly agree that, there is a value for human resource in the university.

4. The results of the statistical analysis (arithmetic mean-standard deviation) of the three variables of accounting for intellectual capital (accounting for human capital, accounting for structural capital, accounting for relational capital), have shown the effect of statistical significance on the value of human resource in the two universities.

5. The results of the analysis of the simple linear regression have shown a strong correlation and significant statistical effect of overall independent study variables combined, (accounting for human capital, accounting for structural capital, accounting for relational capital) on the value of human resources in the tow universities.

6. The study findings have shown that, there are no differences of statistical significance between the responses of the individuals of the sample at each university on the correlation between the accounting for intellectual capital with its three components, (human capital, structural capital, relational capital) and the value of human resources at a significant level of $(a=0.05)$.

Second: Study Recommendations:

In light of said study results, the study concluded with a set of recommendations, including the following:

1. The study recommended the management of the two universities to have a particular interest in the accounting for intellectual capital with its three variables (accounting for human capital, accounting for structural capital, and accounting for relational capital) by utilizing all possible energies in the university in order to enhance the human resources value.

2. The study recommended the management of the two universities to provide the support and assistance programs for the faculty members, and to strengthen the relationships and cooperation with local and international educational and training institutions in a manner which increases the ability of the university to encourage creativity and excellence.

3. The study recommended the two universities to use the relevant methods of accounting measurement to measure the intellectual capital to reflect more confidence in financial statements.

4. The study recommended the management of the two universities to use the best methods upon the disclosure for intellectual capital with its three variables in financial statements and reports, which helps in providing information in a perfect manner to the users.

5. The management of the two universities should work to provide the appropriate environment and transparency in the work of the faculty members in order to provide the best they have got to enhance the educational and teaching process in the university.

6. Due to lack of studies related to the value of human resources, the researchers suggest that, the efforts in conducting study in the subject of intellectual capital in the firms should continue to effect the value of human resources.

\section{References}

Abbas, M. E. (1990). Accounting Theory. Zat Elsalasil Library, Kuwait.

Abdelfatah, R. I. M. (2016). A Proposed Framework for Determining Cost of Disclosure and Report on Knowledge Capital. Journal of Faculty of Commerce, Mansoura University, 4(3). 
Abdelgani, M. A. H. (2010). Accounting for Intellectual Capital and its Effect on the Value of the Firm", A Study Submitted in Partial Fulfilment of the Requirements for the Degree of Master in Cost and Management Accounting, Faculty of Commercial Studies, Sudan University of Science and Technology.

Abdelrahman, M. (2006). Egypt, Intellectual Capital - Transformation Strategy from General Category to Distinguished Category. International House for Cultural Investments.

Abdelwahab, A. M., \& Amer, S. Y. (1984). Human Resources Accounting. Riyadh, Saudi Arabia, Dar Elmarikh.

Adel, H. E., \& Ahmad, A. S. (2013). Egypt, Intellectual Capital - Methods of Measurement and Maintenance. Arab Organization for Administrative Development.

Ahmed, A. (2013). Accounting for Intellectual Capital and its Role in Determining the Quality and Effectiveness of Accounting Information. Unpublished Master thesis, Faculty of Graduate Studies, Sudan University of Science and Technology, Sudan.

Ahmed, M. R. (1990). Economics of Human Resources. Beirut, University House.

Amira, H. E. S. (2007). Accounting for Intellectual Capital and its Effect on Financial Performance of the firmA Quantitative Approach. unpublished Master thesis, Faculty of Commerce, Cairo University.

Ayman, A. M. A. B. (2016). Accounting Theory. Al Ain, University Book House.

Ayman, A. M. A. B. (2017), Accounting of Human Resources and Extent of its Effect on Evaluating and Measuring Performance Efficiency. Germany, Noor Publishing House.

Ayman, A., \& Issa, K. (2017). Methods of Scientific Study and Statistical Analysis: Al Ain, University Book House.

Bashair, K. A. E. K. (2015). Accounting Measurement of Intellectual Capital and its Relation to the Performance of the Firm. Qadisiyah Journal of Administrative and Economic Sciences, 17(4).

Ehilali, E. E. (2011). Managing, Measuring and Developing Intellectual Capital As part of Knowledge Management in Higher Education Institutions. Journal of Specific Education Study, 22(1).

Esam, M. E. (2018). The Effect of Accounting Measurement and Disclosure for Intellectual Capital on Improving the Quality of Accounting Information. Elaqsa University Journal, 22(1).

Flamholtz, E. (1971). Should Your Organization Attempt to Value its Human. https://doi.org/10.2307/41164333

George, M., \& Jeffrey, H. (2013). Voluntary Disclosure of Intellectual Assets and Intellectual Liabilities :'Impact on Financial Performance in Publicly Listed Firms in the United Arab Emirates. Electronic of Knowledge Management, $l 11$.

Hani, M. E. (2008). Intellectual Capital - Contemporary Management Take off. Beirut, Lebanon, Elsahab Publishing House.

Herman, A. T. ( 2005). A Human Resource Accounting Transmission. Shifting.

Indra, A., \& James, G. (2005). An Empirical Investigation of Annual Reporting Trends of Intellectual Capital in Sir Lanka. Critical Perspectives on Accounting, 16. https://doi.org/10.1016/S1045-2354(03)00059-5

Kamal, E. (2010). Dubai, The Problem of Accounting Recognition of Human Resources as a Long-Term Assets. Effect of Human Resources on Enhancing the National Economy.

Kamal, H. G. (2007). Human Resources Accounting- A New Approach to Measure the Value of Human Resources Services. Retrieved from https://www.iasj.net/iasj?func=fulltext\&aId Date of cognizance: $2018 / 5 / 27$

Kohan, N., Rafie, M., \& Hosseini, S. H. (2014). Assessing the Effect of Intellectual Capital on New Product Development" (Case Study: Pharmaceutical Industry of Isfahan Province). International Business and Management, 8.

Magdy, A. M. (2013). Determinants of Accounting Disclosure for Intellectual Capital and its Effect on Performance. A Study Submitted in Partial Fulfilment of the Requirements for the Degree of Master in Accounting, Faculty of Commerce, Banha University.

Mammoth, A. A. R., \& Ahmed, K. K. (2015). The Effect of Application of Intellectual Capital Strategy on Improving the Efficiency of Human Resources Performance. Journal of Studyer, 15.

Modathir, H. S. (2017). Human Resources Management - Views and Trends. Al Ain, University Book House. 
Saad, A. E. (2015). Intellectual Capital and the Challenges Facing Accountants in Measuring it. Faculty of Administrative and Financial Sciences, Irbid National University, 3(2).

Saad, A. E., \& Ahmed, A. S. (2009). Intellectual Capital Management in Business Firms. Amman, Jordan Elyazuri.

Salem, M. S. B. (2014). Measuring the Effect of Intellectual Capital and its Disclosure on the Performance of Firms. Al-Andalus Journal of Human and Social Sciences, 6(1).

Saoud, J. M., \& Jafar, F. N. (2016). Accounting Measurement and Disclosure for Human Capital and its Role in Increasing the Value of Economic Unity. Journal of Faculty of Economics and Administration, Muthanna University, Algeria, 2.

Skyrme, D. (1997). Measuring the Value of Knowledge: Metrics for the Knowledge Based Business. Business Intelligence, 1997, London.

Sulaiman, H. E., \& Ismail, A. B. T. (2014). The Effect of Intellectual Capital on Improving the Profitability of Jordanian Pharmaceutical Industries firms. Jordanian Journal of Business Administration, 10(2).

Tawfig, A. E. (2005). Significance of Accounting for Intellectual Capital and the Determination of its Effect on Feasibility of Accounting Information. Journal of Faculty of Commerce for Scientific Study, Alexandria University, 42(1). https://doi.org/10.1016/B978-0-7506-7799-8.50008-5

Tiwari, R. (2006). Human Resource Accounting- A New Dimension. Retrieved from Http://ssrn.Com/abstract $=961570$

Youssef, A. (2005). Return on Investment in Intellectual Capital - Measuring Economic Value of Employees, Federation of Experts and International Consultants Center, Cairo.

Zahra, A. M. (2013). Trends of Accounting Measurement and Disclosures for Intellectual Capital. An applied Study on the Sudanese Banking Sector, Graduate College, Elneelain University.

\section{Copyrights}

Copyright for this article is retained by the author(s), with first publication rights granted to the journal.

This is an open-access article distributed under the terms and conditions of the Creative Commons Attribution license (http://creativecommons.org/licenses/by/4.0/). 